\title{
IMPACT OF TECHNICAL SPRAYING FACTORS ON VERTICAL LIQUID DISTRIBUTION WITH AGROMEHANIKA AGP 440 AXIAL FAN SPRAYER
}

\author{
Branimir Vujčić, Vjekoslav Tadić, Monika Marković, Jasmina Lukinac-Čačić, Miro Stošić, Ivan Plaščak
}

Original scientific paper The influence of technical spraying factors on vertical distribution of liquid and air velocity was observed and measured with vertical patternator device. In research, Lechler yellow (TR 8002C) and red (TR 8004C) nozzles are used with two different sets of fan rotor blades (two different air velocities) at $540 \mathrm{rpm}$ of PTO. The research was set as controlled three - factorial experiment (without the influence of weather factors) with 8 treatments in 4 repetitions, for each side of Agromehanika AGP 440 axial fan sprayer. Technical spraying factors (ISO nozzle number, settings of fan blades and spraying height) have a high significant impact (**) on the main properties of the research (vertical distribution of liquid and air velocity). By decreasing the ISO nozzle number and air velocity the increase of liquid deposit is found on vertical patternator and with the increase of measuring height a non-uniform distribution of liquid and air velocity is found. In addition, a non-uniform distribution of liquid and air velocity is established between the left and right sides of the machine. With regression analysis between the vertical distribution of liquid and air velocity on both sides of the machine, a statistically significant coherence is determined (left side of the machine: $r=0,96 ; p<0,01$; right side of the machine: $r=0,97 ; p<0,01$ ).

Keywords: air velocity; axial fan sprayer; nozzle; vertical liquid distribution; vertical patternator

Utjecaj tehničkih čimbenika raspršivanja na vertikalnu raspodjelu tekućine s raspršivačem Agromehanika AGP 440

Izvorni znanstveni članak Istražuje se utjecaj tehničkih čimbenika raspršivanja na vertikalnu raspodjelu tekućine i brzine zraka, mjerenu s uređajem vertikalnim peternatorom. Koriste se žute (TR 8002C) i crvene (TR 8004C) Lechler mlaznice te dva različito podešena zakošenja lopatica rotora ventilatora (dvije različite brzine zračne struje) pri 540 o/min PVT-a. Istraživanje se postavlja kao kontrolirani trofaktorijalni pokus (bez utjecaja vremenskih čimbenika) sa 8 tretmana u 4 ponavljanja, za obje strane nošenog aksijalnog raspršivača Agromehanika AGP 440. Tehnički čimbenici raspršivanja (ISO broj mlaznice, podešavanje lopatica ventilatora i visina raspršivanja) ostvaruju vrlo značajan utjecaj (**) na glavna svojstva istraživanja (vertikalna distribucija tekućine i brzine zračne struje). Smanjivanjem ISO broja mlaznice i smanjivanjem brzine zračne struje povećava se količina tekućine deponirana na vertikalnom paternatoru, te povećavanjem visine mjerenja na vertikalnom paternatoru dolazi do neuniformne raspodjele tekućine i brzine zračne struje. Uz navedeno, utvrđuje se neuniformna raspodjela količine tekućine i brzine zračne struje između lijeve i desne strane stroja. Regresijskom analizom između vertikalne raspodjele količine tekućine i brzine zraka s obje strane stroja utvrđuje se visoka statistički značajna povezanost (lijeva strana stroja: $r=0,96 ; p<0,01$; desna strana stroja: $r=0,97 ; p<0,01)$.

Ključne riječi: aksijalni raspršivač; brzina zraka; mlaznica; vertikalna raspodjela tekućine; vertikalni paternator

\section{Introduction}

Considering that in modern agricultural production most of the funds are spent on plant protection, many of the world's researchers are looking for models to reduce these costs. Therefore, a partial answer to this issue is given by agricultural engineering with new machine design and with optimal calibration of the technical spraying factors. Only synergy of accurate agricultural machinery and proper calibration gives good results for plant protection with the ability to reduce costs. This is only possible with increasing of average area coverage which results in better pest control and possibility of treatment reduction. Some of the agricultural engineers suggest that each year before the start of the plant protection, sprayers must pass at inspection on the vertical paternator $[1,2,3]$, with mandatory adjustment to habitus or treetop form. With this testing, the goal is to calibrate vertical liquid distribution to provide the necessary leaf area coverage [4]. Also, it is necessary to carry out field tests of vertical liquid distribution, so that we can point out the nozzles toward the geometry of plantation or to study the best nozzle angles for optimal leaf area coverage [5]. Axial fan sprayers have a vertical liquid distribution in the form of a vertical sinusoid. This is not acceptable for the higher plantations and for the treetops with higher leaf area and density [6], because in this way the area coverage is very poor.
Many researchers are investigating the orientation of the nozzles to a form of permanent crops. From their research it can be concluded that there is no unique solution, and nozzle orientation depends primarily on the shape of the treetop [7, 8]. From the above, it can be seen that many factors affect the vertical distribution of liquid, like: working speed of the fan sprayer, geometry and density of the treetop, droplet size, weather conditions and technical characteristics of the fan sprayers [9].

Also very important technical factor of vertical liquid distribution is air velocity. By the exploitation of the fan sprayers, it is very important that the optimum air velocity reaches the target of spraying and often it happens that the optimum air velocity does not come to the peak branches. This is one of the results of reduced leaf area coverage on higher trees with axial fan sprayers $[10,11]$. This problem can be resolved by using an optimal set of air velocity or by using specific sprayers (radial sprayer with tangential routers) for individual orchard or vineyard [12, 13]. The next problem is decreasing the air velocity by moving the air flow from the deflector. This is an inevitable property of air flow and its decreasing happens because of the friction of surrounding air and air flow from the fan [14]. It can be more or less pronounced depending on the air velocity and on the distance from the fan $[15,16]$. Also, many researchers have noted significant difference between the left and right side of the axial fan sprayer with respect to the air velocity $[9,17]$. 
In Croatia the new law is actual (NN 14/14), linked to sustainable use of pesticides and mandatory inspection of all technical systems in plant protection, so this paper is particularly important for further researches [18].

\section{Objective of the research}

The main objective of this research is to investigate the influence of technical spraying factors (ISO nozzle number, settings of fan blades and spraying height) on the main properties of the research (vertical distribution of liquid and air velocity). Also, the task is to investigate the vertical distribution of liquid and air velocity from both sides of axial fan sprayer, and to find their eventual connection.

\section{Materials and methods}

The researches were conducted at the College of Slavonski Brod - test hall in Grabarje (Brodsko posavska county, Croatia) in July, 2013.

\subsection{Axial fan sprayer Agromehanika AGP 440}

In this study axial fan sprayer Agromehanika AGP 440 is used, which is the most widely used tractor mounted sprayer in the Republic of Croatia. On the sprayer, axial fan is installed ( $825 \mathrm{~mm}$ in diameter) with 8 blades. This configuration provides maximal air flow of $45000 \mathrm{~m}^{3} / \mathrm{h}$ and air velocity of $32 \mathrm{~m} / \mathrm{s}$ at $1800 \mathrm{rpm}$ of the fan rotor. In this research two different settings of blades are used: at position 5 (maximum air velocity) and at position 1 (minimum air velocity) - two extremes that may be used in practice. Around the rotor of axial fan there is a tin fan outlet that directs the airflow towards the nozzles. On each side of the machine there are 6 nozzles forming a semicircle. Axial fan sprayer Agromehanika AGP 440 is shown in Fig. 1.

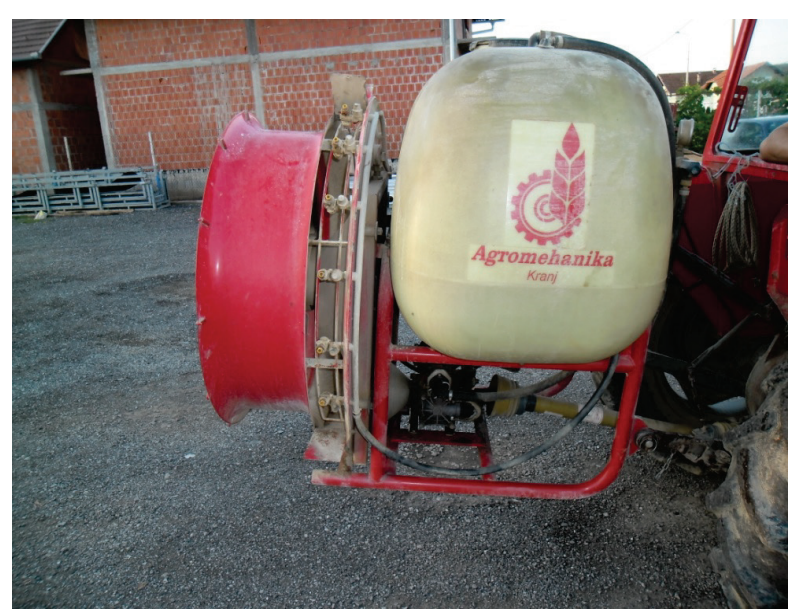

Figure 1 Agromehanika AGP 440 axial fan sprayer

This type of fan sprayer has a plane rectangular air flow and friction occurs only between the airflow and the wider sides of the rectangle (fan outlet - tin deflector). Plan of this air flow is shown in Fig. 2 where is: $h_{0}-$ height of deflector; $b_{0}$ - width of the deflector; $x_{0}$ - area of air flow creating; $U$ - air velocity; $U_{0}-$ initial air velocity; $U_{m}$ - air velocity at distance $x ; b$ - air flow width.

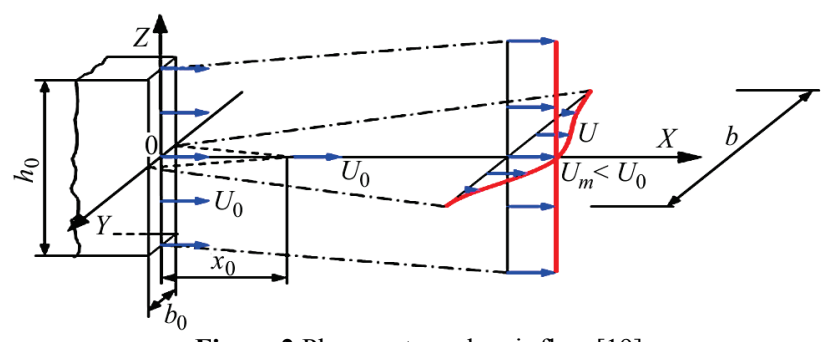

Figure 2 Plane rectangular air flow [19]

Air flow $\left(U_{0}\right)$ mixes with the surrounding air and drags it along. Due to this occurrence, air mass in movement increases. Boundary layers of air flow rub on the surrounding air which results in slowing of the air flow velocity because of the friction of the mentioned layers - average air velocity is measured at distance $x_{0}$. Forming region of the flow $\left(x_{0}\right)$ depends on the mixing coefficient (Reynolds number) and on the width of the tin fan outlet. These two main factors affect the air flow range.

\subsection{Vertical patternator}

Vertical distribution of liquid and air velocity is measured with the vertical patternator, made by the Đuro Đaković factory in Slavonski Brod, Croatia. Dimensions of the patternator are: $140 \times 106 \times 30 \mathrm{~cm}$, while the dimensions of the plates are $100 \times 100 \mathrm{~cm}-40 \mathrm{~cm}$ distance from the ground (Fig. 3). The device consists of 30 horizontally mounted twisted plates whose task is to collect liquid from the sprayer. The distance between the plates is $3 \mathrm{~cm}$. On sideway, the patternator has an overflow positioned at every $10 \mathrm{~cm}$. The overflow is made by silicone hose, which leads the liquid to the gauge glass. Vertical liquid distribution is measured at 2 heights $-40 \mathrm{~cm}$ from the ground up to $140 \mathrm{~cm}$ and from this point to $240 \mathrm{~cm}$. Vertical distribution of air velocity is measured every $10 \mathrm{~cm}$ (use of electric elevator with installed potentiometer made by the Đuro Đaković factory, Slavonski Brod, Croatia) on the outer edge of the patternator plate with the vane anemometer Testo 410-2. Measurements were performed for 1 minute at distance of $150 \mathrm{~cm}$ from the sprayer (in 4 repetitions).

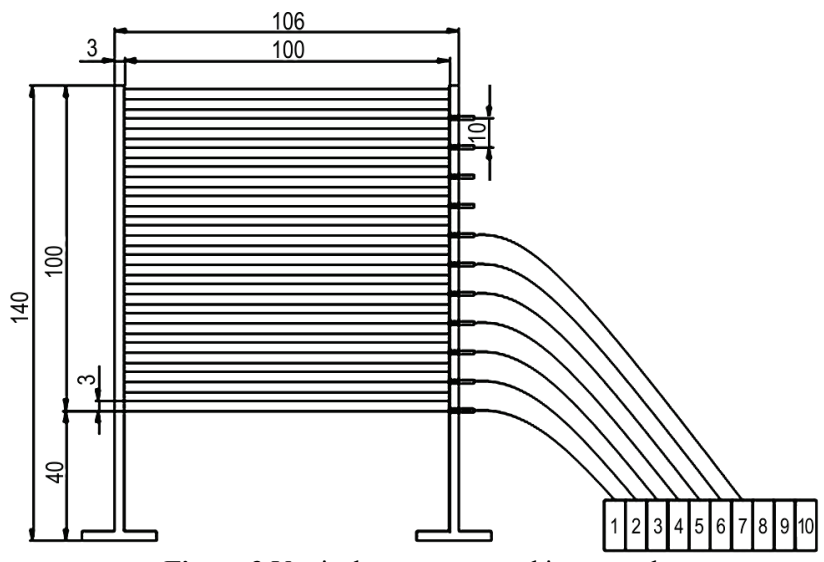

Figure 3 Vertical paternator used in research

\subsection{Nozzles}

The study used two types of nozzles as the first technical spraying factor in statistical analysis: Lechler 
TR $80025 \mathrm{C}$ and TR $8004 \mathrm{C}$. All selected nozzles are marked according to ISO 10625 standard [13]. Dimensions of nozzles are shown in Fig. 4.

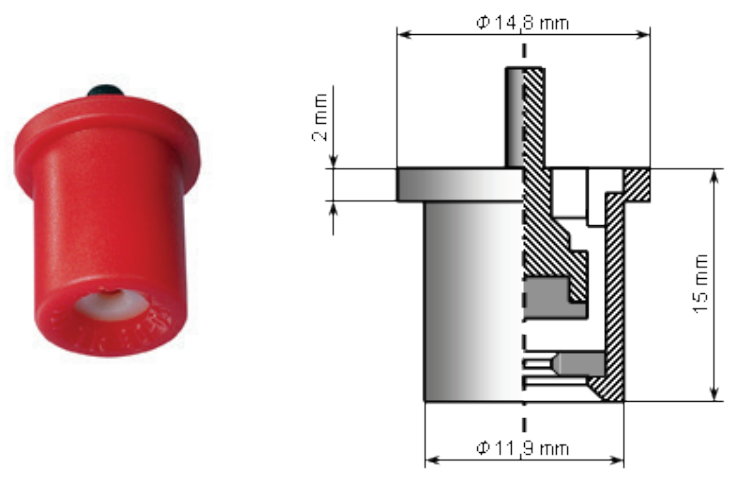

\subsection{Calibration of the axial fan sprayer}

On each side of the axial fan sprayer 6 nozzles were used. With red nozzles (Lechler 8004C) working pressure was set at 3 bars, so liquid flow was 9,60 1/min for each side of the machine. With yellow nozzles (Lechler 8002C) working pressure was set at 12 bars for the same liquid flow as with red nozzles. Working pressure was adjusted on mentioned values due to harmonization of nozzle flow and collected liquid with the capacity of gauge glass (measurement in duration of 1 minute). Also, depending on the ISO nozzle number (04 and 02), working pressure must be different ( 3 and 12 bars) for equal total flow of liquid $(19,20 \mathrm{l} / \mathrm{min}$ in total $)$.

Nozzle orientation was adjusted equally on both sides of the machine, with respect to the horizontal plane. So, first nozzle (first from the ground) was set at angle of $10^{\circ}$; second $-0^{\circ}$, third $-0^{\circ}$; fourth $-10^{\circ}$; fifth $-10^{\circ}$ and sixth at $15^{\circ}$. Power take off (PTO) was set at $540 \mathrm{rpm}$ and control was done with Kimo optical tachometry, model CT100 O.

\section{Results}

The total amount of liquid that must be collected at patternator is $9,6 \mathrm{l} / \mathrm{min}$, but lower values are recorded (from 8,47 to $8,651 / \mathrm{min}$ ). This is the result of drift, friction forces and adhesion that occurs between the molecules of the liquid and metal, so liquid loss is from 7,50 to $11,25 \%$ (Tab. 1 ).

Table 1 Average values of air velocity and amount of liquid measured at vertical paternator

\begin{tabular}{|c|c|c|c|c|c|c|c|}
\hline \multicolumn{8}{|c|}{ TR 8004C } \\
\hline \multicolumn{4}{|c|}{ Sprayers left side } & \multicolumn{4}{|c|}{ Sprayers right side } \\
\hline \multicolumn{2}{|c|}{$\begin{array}{c}\text { Air velocity, } \\
\mathrm{m} / \mathrm{s}\end{array}$} & \multicolumn{2}{|c|}{$\begin{array}{c}\text { Amount of } \\
\text { liquid, } 1\end{array}$} & \multicolumn{2}{|c|}{$\begin{array}{c}\text { Air velocity, } \\
\mathrm{m} / \mathrm{s}\end{array}$} & \multicolumn{2}{|c|}{$\begin{array}{c}\text { Amount of } \\
\text { liquid, } 1\end{array}$} \\
\hline $\begin{array}{l}\text { Posit. } \\
5\end{array}$ & $\begin{array}{c}\text { Posit. } \\
1\end{array}$ & $\begin{array}{c}\text { Posit. } \\
5\end{array}$ & $\begin{array}{c}\text { Posit. } \\
1\end{array}$ & $\begin{array}{l}\text { Posit. } \\
5\end{array}$ & $\begin{array}{c}\text { Posit. } \\
1\end{array}$ & $\begin{array}{c}\text { Posit. } \\
5\end{array}$ & $\begin{array}{c}\text { Posit. } \\
1\end{array}$ \\
\hline 4,70 & 4,60 & 8,55 & 8,47 & 4,10 & 3,70 & 8,58 & 8,65 \\
\hline & Drift, 1 & 1,05 & 1,13 & & Drift, 1 & 1,02 & 0,95 \\
\hline & Drift, \% & 10,93 & 11,77 & & Drift, \% & 10,62 & 9,89 \\
\hline \multicolumn{8}{|c|}{ TR $8002 \mathrm{C}$} \\
\hline 4,80 & 4,70 & 8,51 & 8,88 & 4,00 & 3,70 & 8,76 & 8,81 \\
\hline & Drift, 1 & 1,08 & 0,72 & & Drift, 1 & 0,84 & 0,78 \\
\hline & Drift, $\%$ & 11,25 & 7,50 & & Drift, $\%$ & 8,75 & 8,12 \\
\hline
\end{tabular}

Measured values of liquid loss are not crucial to the final conclusions of this paper, because the mentioned property is unavoidable. Measurement of liquid distribution from left and right side of the sprayers is shown in Tabs. 2 and 3. Blades of the fan are set to position 5 (higher air velocity) and position 1 (lower air velocity). First measurement height was set vertically 40 $\mathrm{cm}$ from the ground up to $140 \mathrm{~cm}$, and second from 140 up to $240 \mathrm{~cm}$.

Table 2 Vertical distribution of liquid with left side of the sprayer

\begin{tabular}{|c|c|c|c|c|c|}
\hline \multicolumn{2}{|c|}{ Technical parameters - treatment } & \multirow{2}{*}{$\begin{array}{c}\text { Amount of } \\
\text { liquid in gauge } \\
\text { glass, ml }\end{array}$} & \multicolumn{2}{|c|}{$\begin{array}{c}\text { Statistical } \\
\text { parameter }\end{array}$} \\
\cline { 1 - 1 } Nozzle & $\begin{array}{c}\text { Set of } \\
\text { blades }\end{array}$ & $\begin{array}{c}\text { Measurement } \\
\text { height }\end{array}$ & $\begin{array}{c}\text { C.V., } \\
\%\end{array}$ \\
\hline TR 8002C & 5 & 1 & 538,00 & 3,55 & 0,66 \\
\hline TR 8002C & 5 & 2 & 313,00 & 2,16 & 0,69 \\
\hline TR 8002C & 1 & 1 & 539,50 & 4,12 & 0,76 \\
\hline TR 8002C & 1 & 2 & 348,75 & 2,87 & 0,82 \\
\hline TR 8004C & 5 & 1 & 539,00 & 4,39 & 0,81 \\
\hline TR 8004C & 5 & 2 & 316,25 & 3,50 & 1,10 \\
\hline TR 8004C & 1 & 1 & 594,00 & 3,26 & 0,55 \\
\hline TR 8004C & 1 & 2 & 253,50 & 4,12 & 1,62 \\
\hline
\end{tabular}

Table 3 Vertical distribution of liquid with right side of the sprayer

\begin{tabular}{|c|c|c|c|c|c|}
\hline \multicolumn{2}{|c|}{ Technical parameters - treatment } & \multirow{2}{*}{$\begin{array}{c}\text { Amount of } \\
\text { liquid in gauge } \\
\text { Nozzle }\end{array}$} & $\begin{array}{c}\text { Set of } \\
\text { blades }\end{array}$ & $\begin{array}{c}\text { Measurement } \\
\text { height }\end{array}$ & \multicolumn{2}{|c|}{$\begin{array}{c}\text { Statistical } \\
\text { parameter }\end{array}$} \\
\cline { 1 - 2 } & 5 & 1 & 519,25 & 0,96 & 0,18 \\
\hline TR 8002C & 5 & 2 & 357,00 & 1,15 & 0,32 \\
\hline TR 8002C & 5 & 1 & 514,75 & 1,71 & 0,33 \\
\hline TR 8002C & 1 & 2 & 366,50 & 1,00 & 0,27 \\
\hline TR 8002C & 1 & 2 & 518,50 & 5,45 & 1,05 \\
\hline TR 8004C & 5 & 1 & 340,00 & 2,16 & 0,64 \\
\hline TR 8004C & 5 & 2 & 502,50 & 3,42 & 0,68 \\
\hline TR 8004C & 1 & 1 & 362,50 & 2,38 & 0,66 \\
\hline TR 8004C & 1 & 2 & & & \\
\hline
\end{tabular}

The measurement results, from 4 repetitions, did not deviate much from each other, so small absolute and relative variations are determined. In Tab. 4 are shown results from the analysis of variance for the vertical liquid distribution on both sprayer sides. In the table, tags are used as follows: $A$ - nozzle type $\left(A_{1}-\right.$ TR $8002 \mathrm{C}$; $A_{2}-$ TR $\left.8004 C\right), B-$ set of fan blades $\left(B_{1}-\right.$ position 5 ; $B_{2}$ - position 1$)$ and $C$ - height of measurement $\left(C_{1}-\right.$ vertically from 40 to $140 \mathrm{~cm} ; C_{2}$ - vertically from 140 to $240 \mathrm{~cm})$.

Considering the there-way factorial analysis of variance and on the basis of the above mentioned results, it is determined that most of the investigated technical spraying factors and their interactions have highly significant impact $(* *)$ or significant impact $(*)$ on the vertical liquid distribution (except interaction $A B$ on the right sprayer side). Similar results are determined for both of the sprayers' sides and it is very noticeable that the amount of the liquid in higher patternators measurement (from 140 to $240 \mathrm{~cm}$ ) is extremely lower. On left side of the sprayer this amount is lower by $55,71 \%$ or by 244,75 $\mathrm{ml}$, and on the right side the amount is lower by $69,39 \%$ or by $157,25 \mathrm{ml}$.

With LSD test it is determined that with increasing of ISO nozzle number and air velocity (different set of fan blades), the amount of liquid measured with vertical paternator is decreasing. Also, as already mentioned, with increasing of measurement height, amount of liquid at vertical paternator is extremely decreasing. 
Table 4 Analysis of variance for the vertical liquid distribution

\begin{tabular}{|c|c|c|c|c|c|c|c|c|c|}
\hline \multirow{2}{*}{\multicolumn{2}{|c|}{ ANOVA }} & \multicolumn{4}{|c|}{ Sprayers left side } & \multicolumn{4}{|c|}{ Sprayers right side } \\
\hline & & $\bar{X}$ & $L S D_{0,05}$ & $L S D_{0,01}$ & $F$ - test & $\bar{X}$ & $L S D_{0,05}$ & $L S D_{0,01}$ & $F$-test \\
\hline \multirow{2}{*}{$A$} & $A_{1}$ & 434,81 & \multirow{2}{*}{4,54} & \multirow{2}{*}{6,26} & \multirow{2}{*}{$52,30 * *$} & 439,37 & \multirow{2}{*}{0,86} & \multirow{2}{*}{1,19} & \multirow{2}{*}{$80,00 * *$} \\
\hline & $A_{2}$ & 425,68 & & & & 430,87 & & & \\
\hline \multirow{2}{*}{$B$} & $B_{1}$ & 426,56 & \multirow{2}{*}{2,62} & \multirow{2}{*}{3,61} & \multirow{2}{*}{$34,20^{* *}$} & 433,68 & \multirow{2}{*}{2,52} & \multirow{2}{*}{3,47} & \multirow{2}{*}{$9,10^{*}$} \\
\hline & $B_{2}$ & 433,93 & & & & 436,56 & & & \\
\hline \multirow{2}{*}{$C$} & $C_{1}$ & 552,62 & \multirow{2}{*}{2,03} & \multirow{2}{*}{2,80} & \multirow{2}{*}{$37647,40 * *$} & 513,75 & \multirow{2}{*}{1,62} & \multirow{2}{*}{2,24} & \multirow{2}{*}{$27364,20 * *$} \\
\hline & $C_{2}$ & 307,87 & & & & 356,50 & & & \\
\hline \multicolumn{3}{|c|}{$A B$} & 4,03 & 5,87 & 79,50 ** & $A B$ & 3,88 & 5,64 & 0,20 n.s. \\
\hline \multicolumn{3}{|c|}{$A C$} & 3,13 & 4,55 & $854,60 * *$ & $A C$ & 2,50 & 3,63 & $4,40 *$ \\
\hline \multicolumn{3}{|c|}{$B C$} & 3,13 & 4,55 & $273,9^{* *}$ & $B C$ & 2,50 & 3,63 & $190,6^{* *}$ \\
\hline \multicolumn{3}{|c|}{$A B C$} & 5,33 & 8,84 & $907,5^{* *}$ & $A B C$ & 4,25 & 7,06 & $41,50 * *$ \\
\hline
\end{tabular}

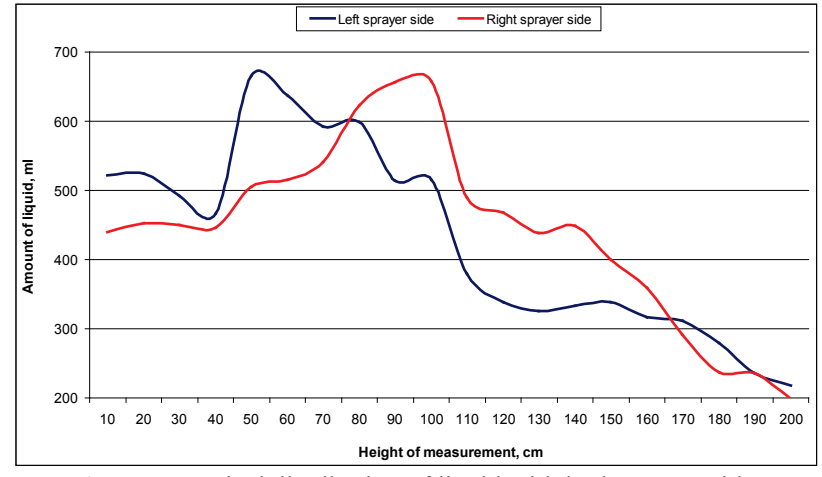

Figure 5 Vertical distribution of liquid with both sprayer sides

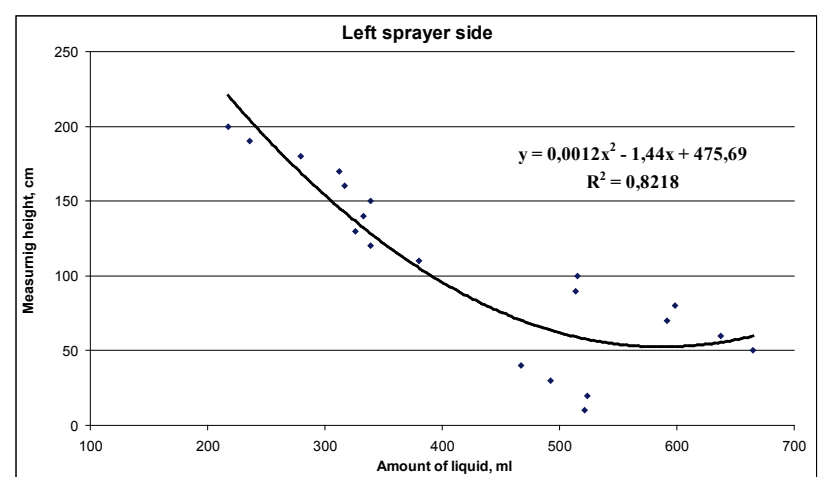

Figure 6 Impact of measuring height at amount of liquid - left side

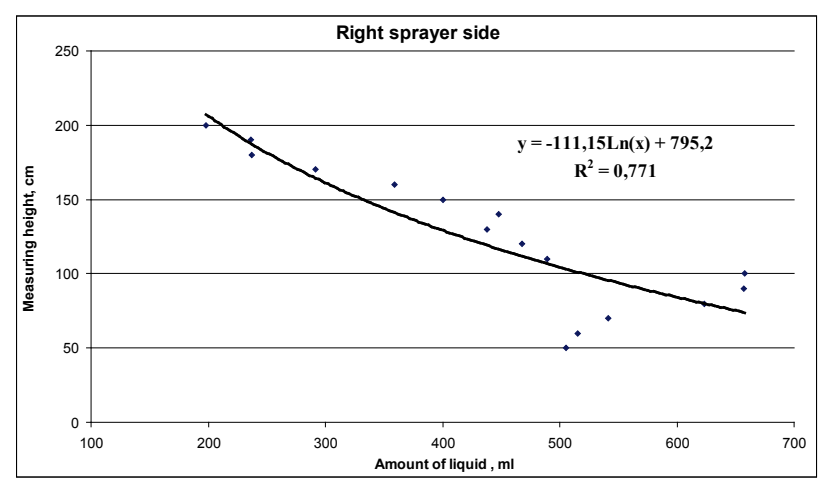

Figure 7 Impact of measuring height at amount of liquid - right side

For a better view of data movement, working width of vertical paternator is divided into 3 parts to show differences between liquid amounts of sprayer sides. With sign test it is determined that the left side of sprayer on the first part has a significantly higher amount of liquid than the right side $(17,93 \%$; $99,91 \mathrm{ml} ; Z=2,26, p<$ $0,05)$. On the second part, right side of the sprayer has a significantly higher amount of liquid $(20,52 \% ; 110,89 \mathrm{ml}$; $Z=2,16, p<0,05)$, and on the third part, there is no statistical difference $(1,19 \% ; 2,44 \mathrm{ml} ; Z=0,40, p>0,05)$ (Fig. 5).

In both cases, with regression analysis (Figs. 6 and 7), it is determined that with increasing the measurement height, the amount of liquid is decreasing (left side: $r=$ $-0,90 ; p<0,05$ - right side: $r=-0,87 ; p<0,05$ ).

In Tab. 5 are shown the results of the air velocity measurement, separately for the left and the right side of the sprayer. The measurement results, from 4 repetitions, did not deviate much from each other, so small absolute and relative variations are determined. Measurement was carried out at every $10 \mathrm{~cm}$ on the outer edge of patternator measuring plate. Air velocities shown in the table are the result of the mean values from both sets of fan blades. As it is shown, at distance of $150 \mathrm{~cm}$ from the sprayer fan outlet, the air velocities are extremely low and insufficient for high quality of plant protection.

Table 5 Results of air velocity measurements

\begin{tabular}{|c|c|c|c|c|c|c|}
\hline $\begin{array}{c}\text { Measuring } \\
\text { height, cm }\end{array}$ & $\begin{array}{c}\text { Sprayers } \\
\text { left side, } \\
\mathrm{m} / \mathrm{s}\end{array}$ & $\sigma$ & $\begin{array}{c}\text { C.V., } \\
\%\end{array}$ & $\begin{array}{c}\text { Sprayers } \\
\text { right side, } \\
\mathrm{m} / \mathrm{s}\end{array}$ & $\sigma$ & $\begin{array}{c}\text { C. } V ., \\
\%\end{array}$ \\
\hline 10 & 5,79 & 0,04 & 0,76 & 3,04 & 0,24 & 7,87 \\
\hline 20 & 5,74 & 0,06 & 1,08 & 4,50 & 0,04 & 0,79 \\
\hline 30 & 5,54 & 0,02 & 0,32 & 4,08 & 0,22 & 5,41 \\
\hline 40 & 5,03 & 0,08 & 1,58 & 4,06 & 0,02 & 0,44 \\
\hline 50 & 6,91 & 0,07 & 1,02 & 4,26 & 0,26 & 6,02 \\
\hline 60 & 6,60 & 0,02 & 0,27 & 4,21 & 0,13 & 3,15 \\
\hline 70 & 6,19 & 0,04 & 0,57 & 4,33 & 0,11 & 2,45 \\
\hline 80 & 6,26 & 0,06 & 0,99 & 5,69 & 0,15 & 2,64 \\
\hline 90 & 5,10 & 0,21 & 4,16 & 6,08 & 0,02 & 0,29 \\
\hline 100 & 5,16 & 0,15 & 2,91 & 6,01 & 0,06 & 1,03 \\
\hline 110 & 3,54 & 0,24 & 6,73 & 3,83 & 0,04 & 1,15 \\
\hline 120 & 3,27 & 0,06 & 1,89 & 4,00 & 0,07 & 1,77 \\
\hline 130 & 3,51 & 0,06 & 1,76 & 3,92 & 0,10 & 2,48 \\
\hline 140 & 3,89 & 0,05 & 1,36 & 4,23 & 0,05 & 1,26 \\
\hline 150 & 4,07 & 0,01 & 0,22 & 3,82 & 0,01 & 0,23 \\
\hline 160 & 3,95 & 0,00 & 0,00 & 3,74 & 0,06 & 1,65 \\
\hline 170 & 4,14 & 0,04 & 1,07 & 2,91 & 0,02 & 0,61 \\
\hline 180 & 3,93 & 0,05 & 1,35 & 2,17 & 0,04 & 2,04 \\
\hline 190 & 3,34 & 0,04 & 1,32 & 2,29 & 0,07 & 3,09 \\
\hline 200 & 2,93 & 0,13 & 4,52 & 1,89 & 0,04 & 2,33 \\
\hline$X$ & 4,74 & 0,07 & 1,53 & 3,95 & 0,09 & 2,34 \\
\hline & & & & & & \\
\hline
\end{tabular}

For a better view of data movement, working width of vertical patternator is divided into 3 parts to show differences between air velocities for sprayer sides. With sign test it is determined that the left side of the sprayer on first part has significantly higher air velocity than the right side $(31,82 \% ; Z=2,36, p<0,05)$. On second part, there is no statistical difference $(8,92 \% ; Z=1,15, p>$ $0,05)$ and on the third part, left side of the sprayer has significantly higher air velocity $(24,93 \% ; Z=2,04, p<$ 0,05) (Fig. 8). 
In both cases, with regression analysis (Figs. 9 and $10)$, it is determined that with increasing the measurement height, air velocity is decreasing (left side: $r=-0,82 ; p<$ $0,05$ - right side: $r=-0,79 ; p<0,05)$.

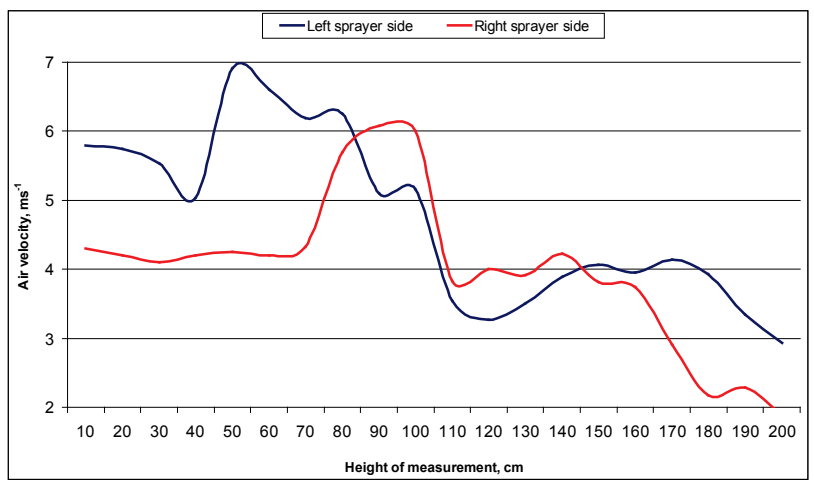

Figure 8 Vertical distribution of air velocity with both sprayer sides

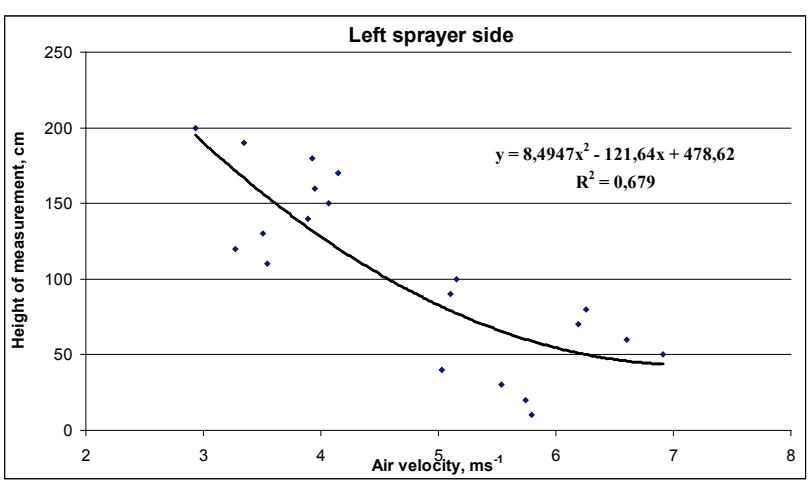

Figure 9 Impact of measuring height at air velocity- left side

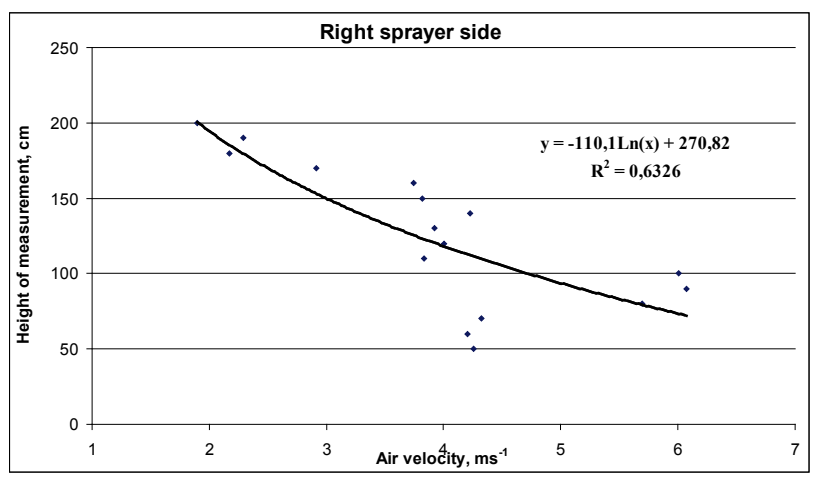

Figure 10 Impact of measuring height at air velocity- right side

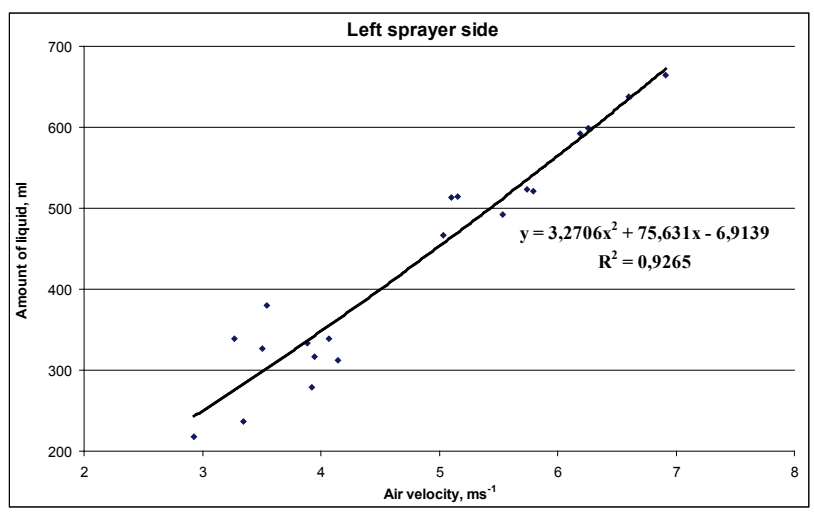

Figure 11 Regression of air velocity and liquid amount - left side

From all previously mentioned results, it is of essential importance to state the relationship between vertical air velocity and liquid distribution. So, regression analysis was carried out to show the basic correlation. In both cases, with regression analysis (Figs. 11 and 12), a statistically significant coherence is determined (left side: $r=0,96 ; p<0,05$ - right side: $r=0,97 ; p<0,05)$.

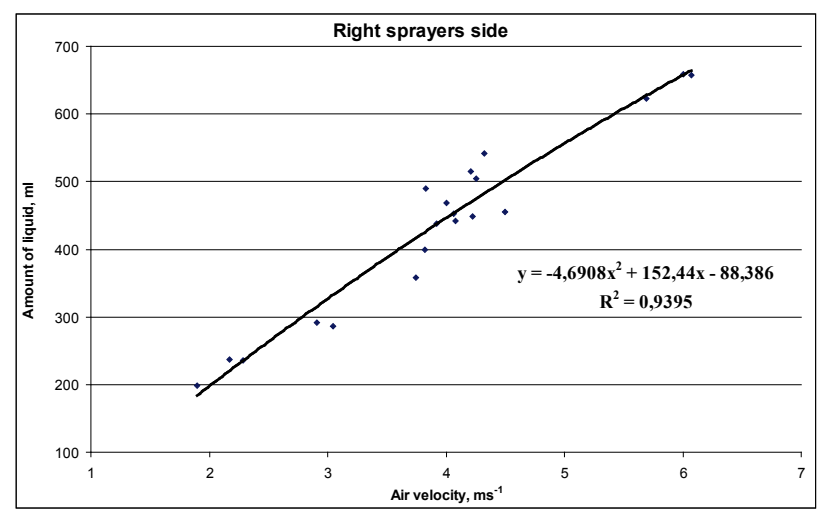

Figure 12 Regression of air velocity and liquid amount - right side

\section{Conclusion}

The main conclusion of this paper is: Technical spraying factors (ISO nozzle number, settings of fan blades and spraying height) have a high significant impact $(* *)$ on the main properties of the research (vertical distribution of liquid and air velocity). By decreasing the ISO nozzle number and air velocity an increase of liquid deposit is found on vertical patternator and by increasing measuring height a nonuniform distribution of liquid and air velocity is found.

Therefore, because of the importance of these facts, every fan sprayer must be tested on vertical patternator before each season. By adjustment of technical spraying factors with this device, nonuniform vertical distribution of liquid is greatly reduced, up to $25 \%$ [20]. This does not mean that the leaf area coverage in specific orchard or vineyard will be satisfactory, so calibration also must be done based on the geometry, density and size of permanent crops [4]. Calibration implies the proper nozzle orientation to the places where the density of treetop is greater [21]. Also, the use of unsuitable type of fan sprayer gives low results of leaf area coverage and reemergence of pests.

In addition, a nonuniform distribution of liquid and air velocity is established between the left and right side of the machine. This claim is the consequence of imperfection of technical construction of axial fan, so in plantation that requires a higher air flow velocity, crop protection may not be satisfying. Differences can be in range from 11 to $25 \%[17,22]$. This problem can be solved by using axial fan sprayers that generate greater air velocities (greater fan diameter) or by higher fan outlet. Also, recommendation is to use radial fan sprayers that generate equal air flow velocity through the entire vertical pattern. With this fan sprayer variation coefficient of vertical air velocity distribution is under $10 \%$, and with axial fan sprayer the value is greater than $26 \%$ [22].

With regression analysis between the vertical distribution of liquid and air velocity on both sides of the machine, a significant coherence is determined. With smaller air flow velocity, the potential of drift is smaller [9] and greater amount of liquid is measured at vertical 
patternator. Also, because of friction forces between air flow and surrounding air, air velocity decreases up to 48 $\%$ at distance of $2 \mathrm{~m}$ from the fan outlet [15]. In this paper air flow velocity at distance of $1,5 \mathrm{~m}$ from the fan outlet was measured in the range from 4 to $4,70 \mathrm{~m} / \mathrm{s}$. Determined values are unsatisfactory for successful crop protection and they must be greater (up to $15 \mathrm{~m} / \mathrm{s}$ ) for satisfactory deposit and leaf coverage inside the canopy $[11,23]$.

The results and the scientifically based conclusions of this paper can serve all agricultural producers, because so far there has been no scientifically based research related to this issue in Croatia. Also, it is particularly important to further investigate the technical spraying factors of the plant protection, with the possibility of reducing production costs based on the effective calibration of fan sprayer [24].

\section{Acknowledgements}

This paper is written in the framework of the research of Branimir Vujčić and his Doctoral thesis.

\section{References}

[1] Biocca, M.; Mattera, M.; Imperi, G. A New Vertical Patternator to Evaluate the Distribution Quality of Vineyards and Orchards Sprayers. // Fructic 05, 2 - 16 September 2005, Montpellier France, pp. 653-660.

[2] Pergher, P.; D'Antonio, C. Calibration of a vineyard sprayer using a lamellate patternator. // Atti delle Giornate Fitopatologiche (pt. 1), (2007), pp. 285-290.

[3] Pergher, G.; Rizzi, C. Vertical spray patterns for sprayer calibration. // Rivista di Ing. Agraria. 36, 1(2008), pp. 5963.

[4] Gil, E.; Badiola, J. Design and Verification of a Portable Vertical Patternator for Vineyard Sprayer Calibration. // Engineering in Agriculture. 23, 1(2007), pp. 35-42. DOl: 10.13031/2013.22328

[5] Celen, I. H. Effect of Angle of Sprayer Deflector on Spray Distribution in Dwarf Apple Trees. // Journal of Agronomy. 7, 2(2008), pp. 206-208. DOI: 10.3923/ja.2008.206.208

[6] Pergher, G. Field evaluation of a calibration method for air assisted sprayers involving the use of a vertical patternator. // Crop Protection. 23, (2004), pp. 437-446. DOl: 10.1016/j.cropro.2003.09.015

[7] Svensson, S. A.; Brazee, R. D.; Fox, R. D.; Williams, K. A. Air jet velocities in and beyond apple trees from a two-fan cross-flow sprayer. // Transactions of the ASAE. 46, 3(2003), pp. 611-621. DOI: 10.13031/2013.13587

[8] Rizzi, C.; Pergher, G. Evaluation of different calibration methods for adjusting a conventional axial fan sprayer. // Atti delle Giornate Fitopatologiche (pt. 2). (2004), pp. 3-10.

[9] Tadić, V. Impact of technical spraying factors on leaf area coverage in permanent crops, $\mathrm{PhD}$ thesis, Agricultural faculty in Osijek, 2013 (in Croatian).

[10] De Moor, A.; Langenakens, J.; Vereecke, E. Image analysis of water sensitive paper as a tool for the evaluation of spray distribution of orchard sprayers. // Aspects of Applied Biology. 57, (2000), pp. 329-341.

[11] Farooq, M.; Salyani, M. Sprayer air energy demand for satisfactory spray coverage in citrus applications. // Proc. Fla. State Hort. Soc. 116, (2003), pp. 298-304.

[12] Salyani, M.; Koo, Y. M.; Sweeb, R.D. Spray Application Variables Affect Air Velocity and Deposition Characteristic of a Tower Sprayer. // Florida Agricultural Experiment Station Journal. 113, (2000), pp. 96-101
[13] Banaj, Đ.; Tadić, V.; Banaj, Ž.; Lukač, P. Improving of pesticide application techniques, University textbook, Agricultural faculty in Osijek, 2010 (in Croatian).

[14] Fox, R. D.; Brazee, R. D.; Svensson, S. A.; Reichard D. L. Air Jet Velocities From a Cross-flow Fan Sprayer. // Transactions of the ASABE. 35, 5(1992), pp. 1381-1384. DOI: $10.13031 / 2013.28744$

[15] Zhu, H.; Brazee, R. D.; Derksen, R. C.; Fox, R. D.; Krause, C. R.; Ozkan, H. E.; Losely, K. A specially designed air assisted sprayer to improve spray penetration and air jet velocity distribution inside dense nursery crops. // Transactions of the ASABE. 49, 5(2006), pp. 1285-1294. DOI: $10.13031 / 2013.22037$

[16] Fox, R. D.; Brazee, R. D.; Svensson, S. A.; Reichard D. L. Air Jet Velocities From a Cross-flow Fan Sprayer. // Transactions of the ASABE. 35, 5(1992), pp. 1381-1384. DOI: $10.13031 / 2013.28744$

[17] Godyn, A.; Holownicki, R.; Doruchowski, G.; Swiechowski, W. Dual - fan Orchard Sprayer with Reversed Air-stream - Preliminary Trials. // Agricultural Engineering International, The CIGR Ejournal. 10, (2008), pp. 1-13.

[18] Banaj, Đ.; Tadić, V.; Petrović, P. Testing of technical systems in crop protection in Republic of Croatia. // Actual Tasks on Agricultural Engineering, Opatija, 2012, pp. $305-$ 310 (in Croatian).

[19] Berčič, S. Composed air flow in pesticide spraying. // Agric. conspectus scientificus. 64, 3(1999), pp. 161-177.

[20] Pergher, G.; Balsari, P.; Cerruto, E.; Vieri, M. The relationship between vertical spray patterns from air assisted sprayers and foliar deposit in vine canopies. // Riv. di Ing. Agr. 1(2002), pp. 27-31.

[21] Celen, I. H.; Durgut, M. R.; Avci, G. G.; Kilic, E. Effect of air assistance on deposition distribution on spraying by tunnel - type electrostatic sprayer. // African Journal of Agricultural Research. 4, 12(2009), pp. 1392-1397.

[22] Tadić, V.; Banaj, Đ.; Petrović, D.; Knežević, D.; Lukinac, J.; Menđušić, I. Air flow and velocity with different types of mistblowers. // Agronomy Journal. 75, 4(2013), pp. 181195

[23] Svensson, S. A. Converging air jets in orchard spraying influence on deposition, air velocities and forces on trees, 2001, PhD thesis, University of Ohio, USA

[24] Sedlar, A. D.; Bugarin, R. M.; Nuyttens, D.; Turan, J.; Zoranovic, M. S.; Ponjican, O. O.; Janic, T. V. Quality and efficiency of apple orchard protection affected by sprayer type and application rate. // Spanish Journal of Agricultural Research. 11, 4(2013), pp. 935-944. DOl: 10.5424/sjar/2013114-3746

\section{Authors' addresses}

Branimir Vujčić, PhD

College of Slavonski Brod

Dr. Mile Budaka 1, 35000 Slavonski Brod, Croatia

Tel: +38535492807

E-mail: bvujcic@vusb.hr

Vjekoslav Tadić, PhD

Faculty of Agriculture,

J. J. Strossmayer University of Osijek,

Kralja Petra Svačića 1 d, 31000 Osijek, Croatia

Tel: +38531554877

E-mail: vtadic@pfos.hr

Monika Marković, PhD

Faculty of Agriculture,

J. J. Strossmayer University of Osijek,

Kralja Petra Svačića, 1 d, 31000 Osijek, Croatia

Tel: +38531554889

E-mail: mmarkovic@pfos.hr 
Doc. Jasmina Lukinac - Čačić, PhD

Faculty of Food Technology,

J. J. Strossmayer University of Osijek

Franje Kuhača 20, 31000 Osijek, Croatia

Tel: +38531224397

E-mail: jlukinac@ptfos.hr

Doc. Miro Stošić, PhD

Faculty of Agriculture,

J. J. Strossmayer University of Osijek

Kralja Petra Svačića 1 d, 31000 Osijek, Croatia

Tel: +38531554 896

E-mail: mstosic@pfos.hr

Doc. Ivan Plaščak, PhD

Faculty of Agriculture,

J. J. Strossmayer University of Osijek

Kralja Petra Svačića 1 d, 31000 Osijek, Croatia

Tel: +385 31554883

E-mail: iplascak@pfos.hr 